\title{
Kyrieleis' vasculitis in acute retinal necrosis
}

This article was published in the following Dove Press journal:

Clinical Ophthalmology

16 July 2010

Number of times this article has been viewed

\author{
Ester Francés-Muñoz' \\ Roberto Gallego-Pinazo' \\ Ruth López-Lizcano' \\ Salvador García-Delpech' \\ J Luis Mullor ${ }^{3}$ \\ Manuel Díaz-Llopis ${ }^{1,2}$ \\ 'Department of Ophthalmology, \\ Hospital La Fe,Valencia, Spain; \\ ${ }^{2}$ University of Valencia, Valencia, Spain; \\ ${ }^{3}$ Unit of Experimental Ophthalmology. \\ Fundación para la Investigación del \\ Hospital Universitario La Fe.Valencia, \\ Valencia, Spain
}

Correspondence: Ester Francés-Muñoz Gran Vía Germanias n ${ }^{\circ}$ 45-3I,

46006 Valencia, Spain

Tel +34 66949457l

Email esterfrances37@hotmail.com

\begin{abstract}
We report the first case in the literature of Kyrieleis' vasculitis related to acute retinal necrosis by Varicella zoster virus in a 76-year-old woman with bilateral involvement. In our patient the arterial lesions appeared 15 days after the initial presentation.
\end{abstract}

Keywords: Kyrieleis' vasculitis, retinal necrosis, herpes virus

Kyrieleis' vasculitis ${ }^{1}$ is a rare condition in which white-yellowish exudates are placed in a beaded pattern within the retinal arteries. ${ }^{2}$ It is predominantly associated with toxoplasma infection but has been described in tuberculosis, syphilis, and mediterranean spotted fever. ${ }^{3,4}$ We describe a patient who developed Kyrieleis' plaques in the setting of an acute retinal necrosis.

A 76-year-old white immunocompetent woman presented with red eye, floaters and blurry vision in her left eye for one week. Visual acuity was 0.5 LogMAR, anterior uveitis with granulomatous keratic precipitates, vitreitis, and patchy white multifocal and confluent areas in the mid and far periphery of the retina (Figure 1). Polymerase chain reaction of aqueous was positive for Varicella zoster virus (VZV). We started treatment with oral valacyclovir, intravitreous foscarnet injections, and retinal photocoagulation of the necrotic areas (Figure 2). In spite of those treatments the right eye was affected one week later. Segmental arteritis with Kyrieleis' plaques (Figures 3 and 4) were observed in both eyes with associated cicatricial retinitis two weeks later. Final visual acuity was 0.60 LogMAR in left eye and 0.30 LogMAR in right eye.

To our knowledge this is the first report of Kyrieleis' vasculitis in acute retinal necrosis by VZV. Kyrieleis' plaques are always associated with inflammation. Its presence reflects the severe intraocular inflammation experienced by the eye, but it does not worsen the prognosis. It is difficult to explain the "segmental arteritis", Griffin and Bodian believed the plaques on the vessels possibly represented migration of exudates from the active choroiditis to the periarterial sheaths. ${ }^{5}$ However, this does not seem feasible because the vessels are not sheathed. As there is no pathological study available in the literature, the nature of the beads is still unknown. In our patient the arterial lesions appeared about 15 days after the initial presentation. It is possible that they may represent an immunological response to an infectious agent resulting in the deposition of immune cells and/or inflammatory debris within or adjacent to the vessel wall.

\section{Disclosure}

No conflicts of interest were declared in relation to this paper. 


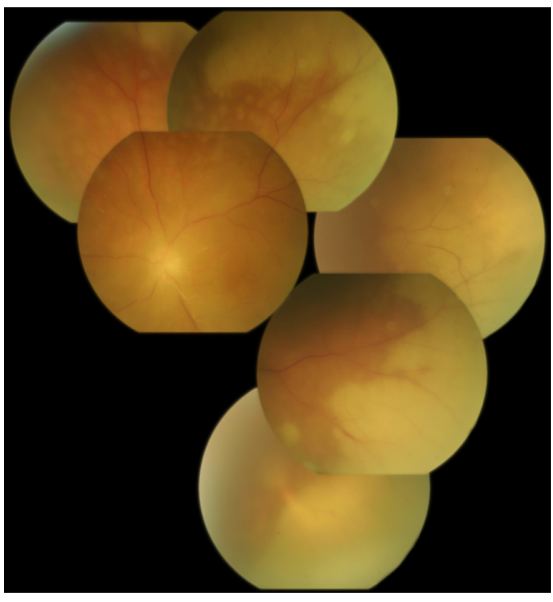

Figure I Montage photo of initial presentation with large confluent areas of retinal necrosis.

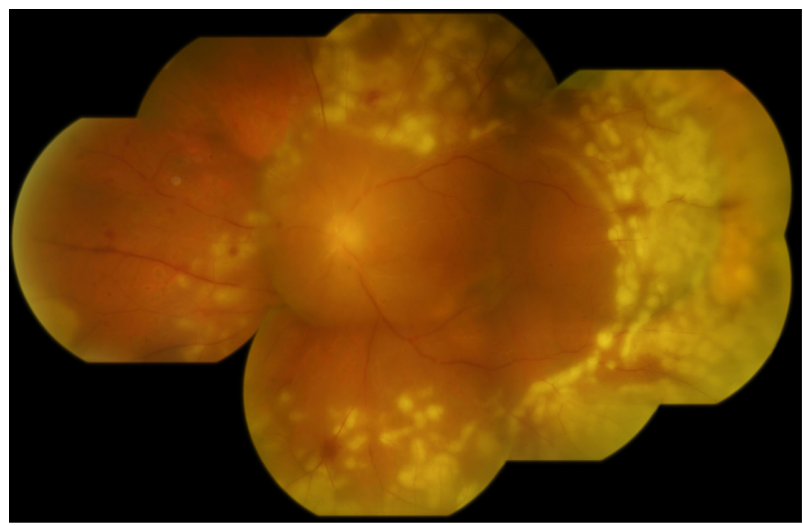

Figure 2 Montage photo after laser photocoagulation.

\section{References}

1. Kyrieleis W. Uber atypische gerfaesstuberkulose der netzhaut. Arch Augenheilkd. 1933;107:182-190.

2. Jain IS, Sing K. Segmental arteritis. Indian J Ophthalmol. 1966;14:229-231.

3. Krishnamurthy R, Cunningham ET. Atypical presentation of syphilitic uveitis associated with Kyrieleis plaques. Br J Ophthalmol. 2008;92:1152-1153.

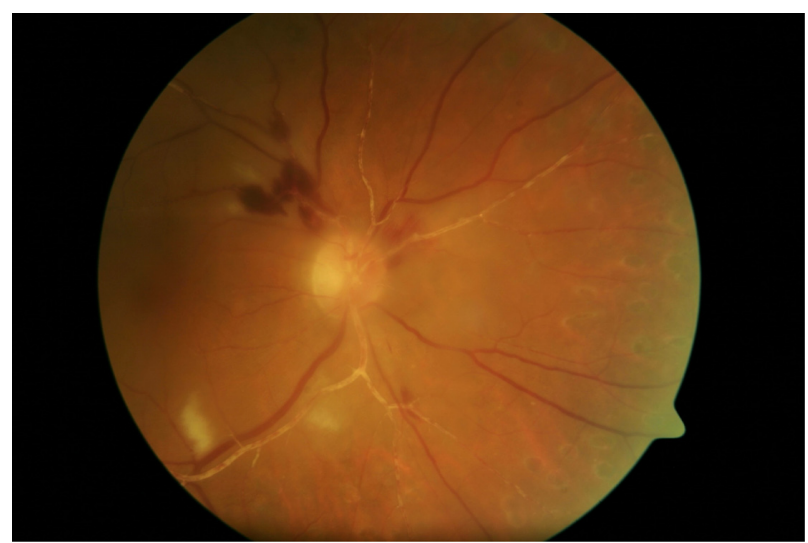

Figure 3 Kyrieleis' pattern of arteritis is present as white plaques within the artery that appear nodular and do not extend outside the vessel.

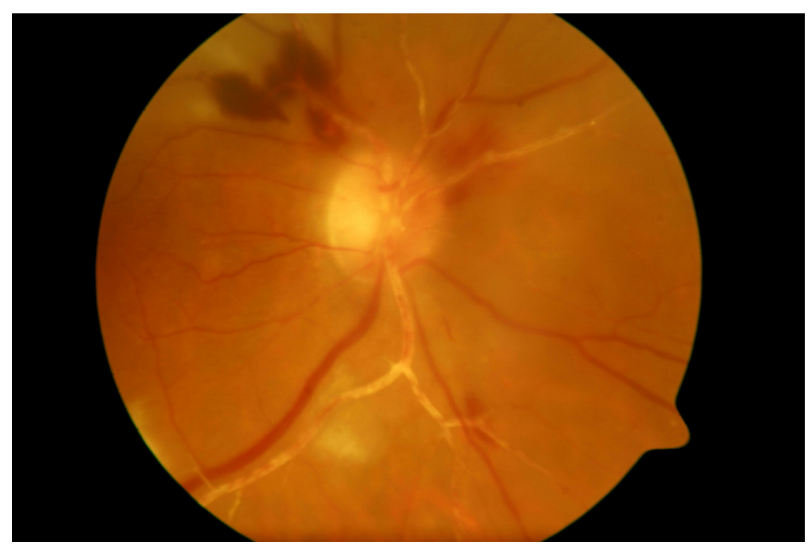

Figure 4 Magnification of Kyrieleis' plaques within the arteries.

4. Khairallah M, Ladjimi A, Chakroun M, et al. Posterior segment manifestations of Rickettsia conorii infection. Ophthalmol. 2004; 111:529-534.

5. Griffin AO, Bodian M. Segmental retinal periarteritis: a report of three cases. Am J Ophthalmol. 1959;47:544.
Clinical Ophthalmology

\section{Publish your work in this journal}

Clinical Ophthalmology is an international, peer-reviewed journal covering all subspecialties within ophthalmology. Key topics include: Optometry; Visual science; Pharmacology and drug therapy in eye diseases; Basic Sciences; Primary and Secondary eye care; Patient Safety and Quality of Care Improvements. This journal is indexed on

Submit your manuscript here: http://www.dovepress.com/clinical-ophthalmology-journal

\section{Dovepress}

PubMed Central and CAS, and is the official journal of The Society of Clinical Ophthalmology (SCO). The manuscript management system is completely online and includes a very quick and fair peer-review system, which is all easy to use. Visit http://www.dovepress.com/ testimonials.php to read real quotes from published authors. 